\title{
DESIGN BRANDING AND IMPLEMENTATION OF VISUAL IDENTITY FOR “KEDAI OMAH JLAMPRANG” PEKALONGAN - CENTRAL JAVA
}

\author{
Noor Udin, Arif Priyono SA, Tunjung Riyadi \\ Bina Nusantara University, Indonesia. \\ nudin@binus.edu
}

\begin{abstract}
Empowering the community is one of a series of activities that must be carried out by a lecturer at Binus University. This empowerment program has been implemented in various cities and regions in Indonesia, including in the Krapyak, Pekalongan City. This program involves lecturers from various programs at Binus University, such as from the Architecture department, interior design department, hotel management department, tourism department, management department, marketing communication department and also visual communication design department. There are a variety of training materials designed to develop the mindset and economic independence activities of the PKK and Karang Taruna groups in the Krapyak area, Pekalongan City. Empowerment is summarized in the establishment of Kedai Omah Jlamprang, an integrated shop offering culinary specialties of Pekalongan City, batik and various Pekalongan City handicraft products, providing a place to gather in developing the creative ideas of the community, and various activities that support the creation of Krapayak people's economic independence, so as to be able to advance this area in an integrated manner. Support by the department of visual communication design provided in the form of training in recognizing and implementing branding programs for Kedai Omah Jlamprang so that it has a strong visual identity. Aimed at the store manager consisting of the PKK group and Karang Taruna youth group, Krapyak, Pekalongan City.
\end{abstract}

Keywords : Empowering Society, Workshop, Identitas Visual, Branding Activity

\section{INTRODUCTION}

Empowerment in the community becomes one of the mandatory duties of a lecturer listed in the Tridarma of higher education. It is fundamental that community empowerment is aimed at one of the problems that is the focus of its solution related to poverty that occurs in people in Indonesia (Mustangin, 2017). In various regions in Indonesia various forms of empowerment have been carried out involving various elements of society, government institutions, educational institutions, nongovernmental organizations, and existing institutions and organizations of the community. Forms of empowerment include various programs that are tailored to the problems and potential of the community to be addressed. According to Mustangin, that Indonesia has a variety of potential both natural and cultural potential, but the diversity of potential is not much utilized by the community (Mustangin, 2017). This diversity of cultural potential allows many regions in Indonesia to have their own identities, not just economic problems but also socio-cultural empowerment (Andriyani: 2017), so the goal is awareness of stagnation that will last for a long period of time.

Pekalongan City is known as a city that has very strong cultural authenticity, Pekalongan is known as a city of batik, even on December 1, 2014, UNESCO chose Pekalongan as "A world creative city from UNESCO in the category of crafts and folk art". In fact it is the only creative city in Southeast Asia (Pujangga, 2014). Pekalongan City is a member of the UNESCO Creative Cities Network along with 68 other cities in the world. Pekalongan City brand awareness was expressed by the major of Pekalongan Dr. HM. Basyir Ahmad, who said that, in building a brand, increased the image and economic growth of the city of Pekalongan through its superior product, namely batik (Kompasiana: 2019). Other potentials of the city of Pekalongan are typical culinary delights such as Rice Megono, Coto Taoto and others that deserve to be empowered to advance the Pekalongan community.

According to the Pekalongan City Public Works Office, there are several problems in Pekalongan City, specifically in the Krapyak area, which are associated with inundations originating from the "Loji" river (rob) river runoff that occurs periodically throughout the year (for more than 8 years to date). Decreased Road Quality and Optimal Drainage Function due to Rob. Road improvements that have been carried out by the City Government have not resulted in a better quality of life as long as the river overflow is not addressed. As well as environmental problems arising from the batik industry. In addition there are also social problems that occur, among them, there are still many people who 
throw littering so that it makes the quality of the environment and deteriorating health, also the absence of sustainable economic activity, most of the fishermen are laborers so that it has a high level of economic vulnerability as well as problems other societies (Department of Public Works: 2018). The problems above form the mindset of the people who are less profitable, so the need for empowerment is able to change the mindset that is more advanced.

Community groups that are members of the PKK (Family Welfare Development) and youth groups in Karang Taruna, Krapyak, Kota Pekalongan are active and open enough people to new things. Community Development Academy (CDA) from Binus University prepared an empowerment program that was specifically designed and adapted to the conditions, problems and potential of the Krpayak community. This partnership program is organized by establishing an activity unit that is managed by elements of the Krapyak community through the establishment of a restaurant business named Kedai Omah Jlamprang. The establishment of this business has become a collective work involving community, government and CDA Binus University to collaborate to develop it.

As an entity, Kedai Omah Jlamprang is a brand, which must be discussed and known for its position in accordance with the conversation. The first thing to do is brand awareness, which in general is very minimal in understanding about this activity. Most of the SMEs assume that the brand is only a label, not part of a marketing strategy (Noor Udin, 2011). Branding activity is known as a source of cost (cost center) instead of profit source (profit center), so the profit is still underestimated. Another thing that makes us aware about the weakest point of UKM is the ability, namely the ability, knowledge, skills of UKM (Yuswohady, 2013). The rise of SMEs is the beginning of awareness of local uniqueness that still provides enough space for freedom. Local challengers in competing with the uniqueness offered. Likewise with "Kedai Omah Jlamprang" which will be managed together with those supported by brands that have high competitiveness, as well as what is needed to be developed sustainably.

\section{METHODS}

The community empowerment activities carried out in the Krapyak area, Pekalongan are practices based research that carried out jointly with the local PKK community group and youth organizations. The material presented includes understanding the problem, analysis, concepts and exploring ideas and applying the design of identity branding. Activities carried out through training on the introduction of the concept of branding in general; brand understanding, branding goals, determining brand names, designing brand identities, implementing brand identity and steps for brand maintenance.

\section{RESULT AND DISCUSSION}

Community empowerment is an economic development concept that applies values to build a new, participatory, people-oriented paradigm. In encouraging empowerment (empowering) can be studied in aspects of ENABLING that is creating complexity that enables the potential of the community to develop. The second aspect is EMPOWERMENT which is gathering the potential needed by the community through the steps needed to provide various inputs and opening various opportunities that will make the community more empowered (Noor: 2011). The things above are aligned steps driven by the Binus University CDA (Community Development Academy) team. The partnership developed is a collaborative pattern that promotes a commensurate hierarchy, thus creating an atmosphere of interrelation and mutual development with the same goals. Krapyak area is a center of batik that has special characteristics and has a strong character, Jlamprang motif is a potential that is owned by the community once it becomes an opportunity to be developed and appointed as the core value for Kedai Omah Jlamprang

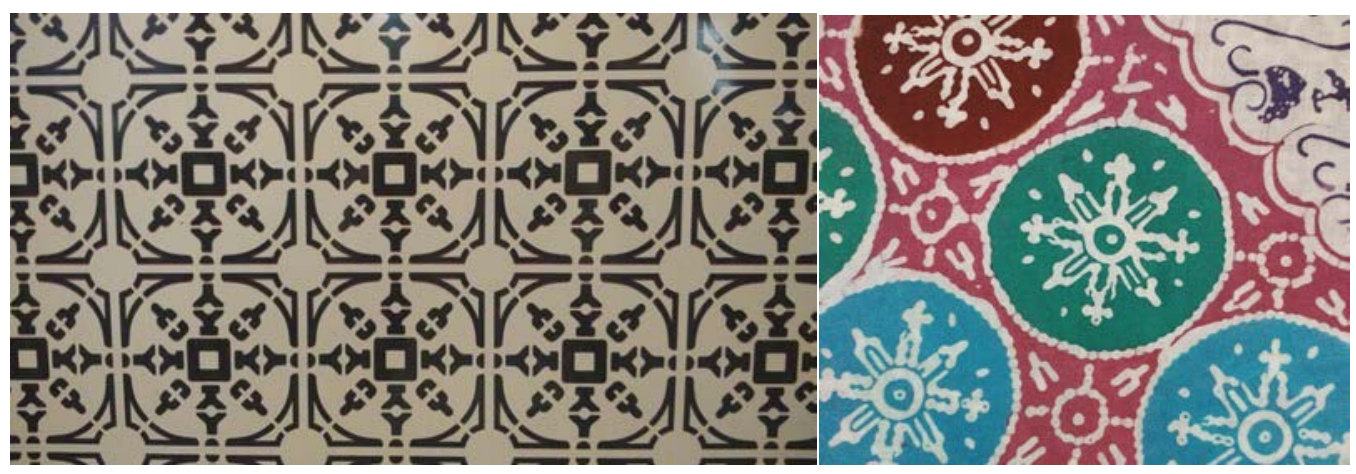

Figure 1. Jlamprang batik, the original Pekalongan batik motif (source : cintapekalongan.com, 2019) 
The first training activity was branding awareness of the potential of Kedai Omah Jlamprang . Jlamprang ornamen/ motif is used as the main entrance in branding activities. In line with various other activities, the Visual Communication Design team, School of Design, Binus University also utilized the Jlamprang motif as part of the visual strategy expressed through mural art.

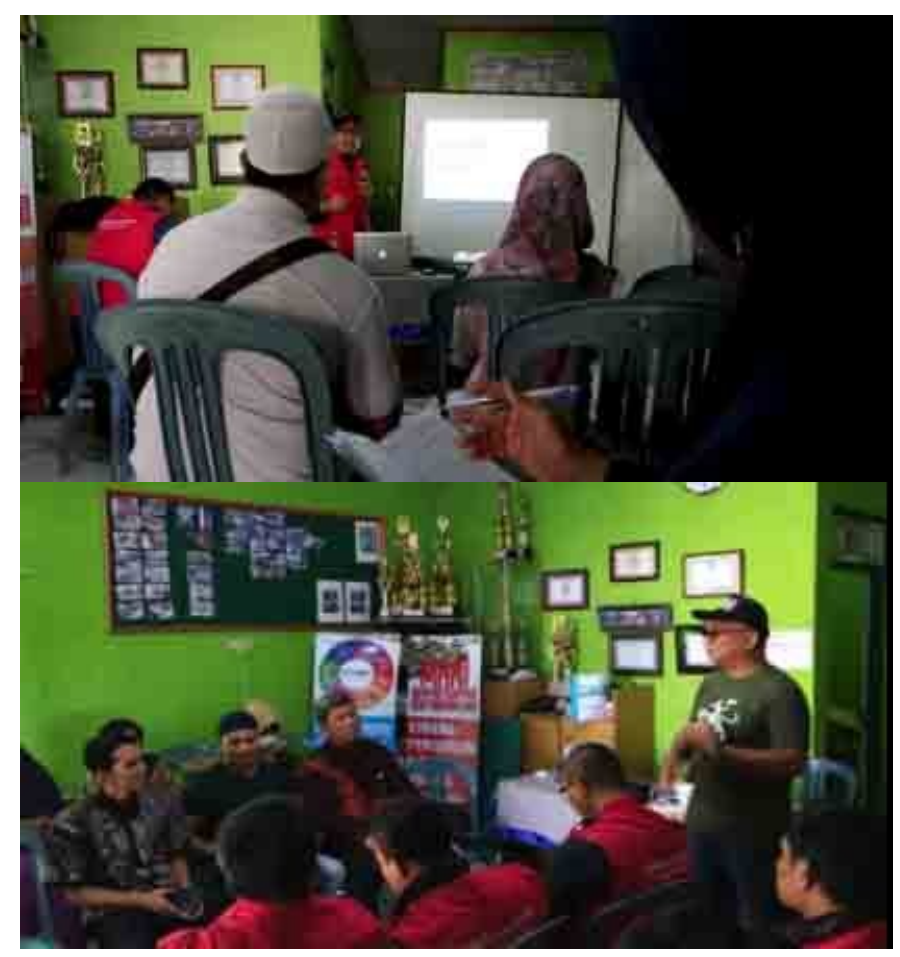

Figure 2. Branding training activities for the PKK and Karang Taruna Krapyak Lor communities, Kota Pekalongan (source: Author, 2019)

The Jlamprang ornament/ motif that has been rooted in the Pekalongan community is a means of emotional binding both from the community such as Karang Taruna and PKK, the Pekalongan City Government and also the Binus University lecturer team in providing empowerment material for workshop. "Jlamprang's motives" provide the same breath reinforcing collaboration patterns and are easily accepted by the wider Pekalongan community who will become the target market of Kedai Omah Jlamprang.
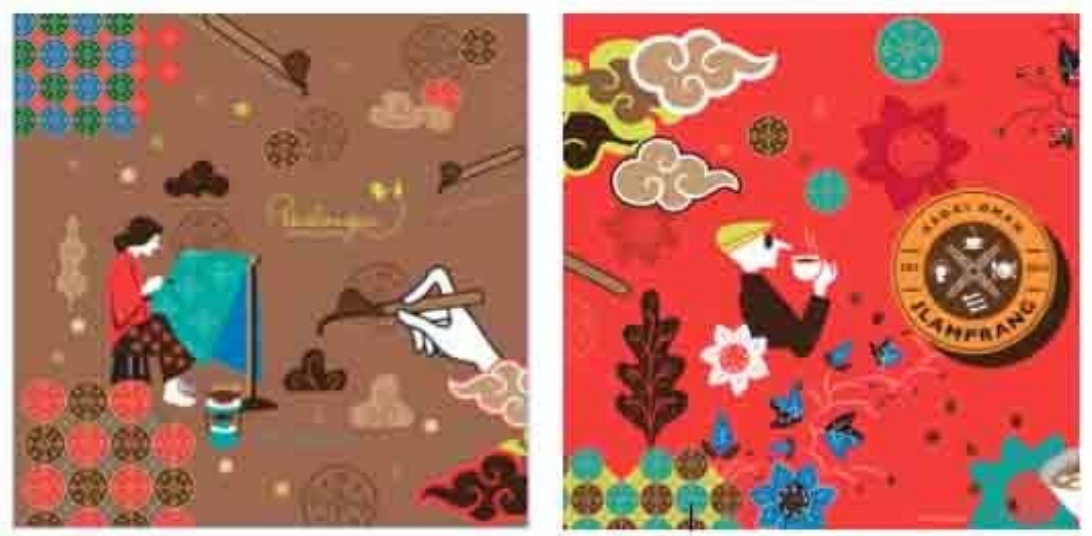

Figure 3. Mural Art Design (source : Author, 2019)

Integrating the unique tradition that carries the concept of Kedai Omah Jlamprang as a culinary provider of Pekalongan, providing batik products and Pekalongan typical craftsmanship, being a meeting point for the creative community and being a means of connecting various parties to 
collaborate in order to achieve a scalable common goal and suistanable. The visual communication and branding design team designed a visual approach that utilizes the value of tradition expressed through the Jlamprang motif with a modern design presentation that is familiar with the current atmosphere. Figure "Mas Petruk", who became a special figure in Central Java and surrounding areas, is the character that is displayed so that it becomes a strong red thread.

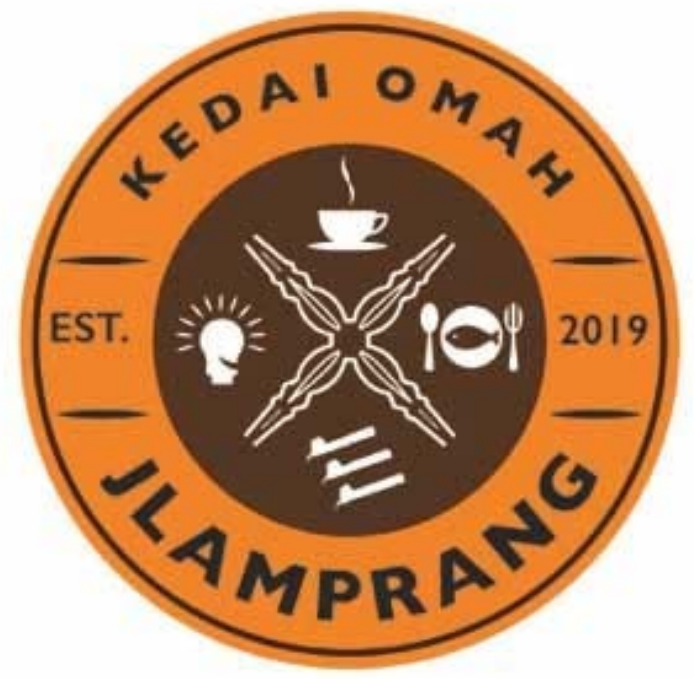

Figure 4. Logo Kedai Omah Jlam[rang (source : Author, 2019)

Visual identity of Kedai Omah Jlamprang are stillated from the distinctive Jlamprang batik motif, the circle being the basic form of the shop logo. While the elements are being used to express the concept of the shop as mentioned above. Identity uses colors that are widely presented in Jlamprang motifs, namely warm colors. This color represents the hospitality of the store's service. Warm colors also give a wide and comfortable impression.
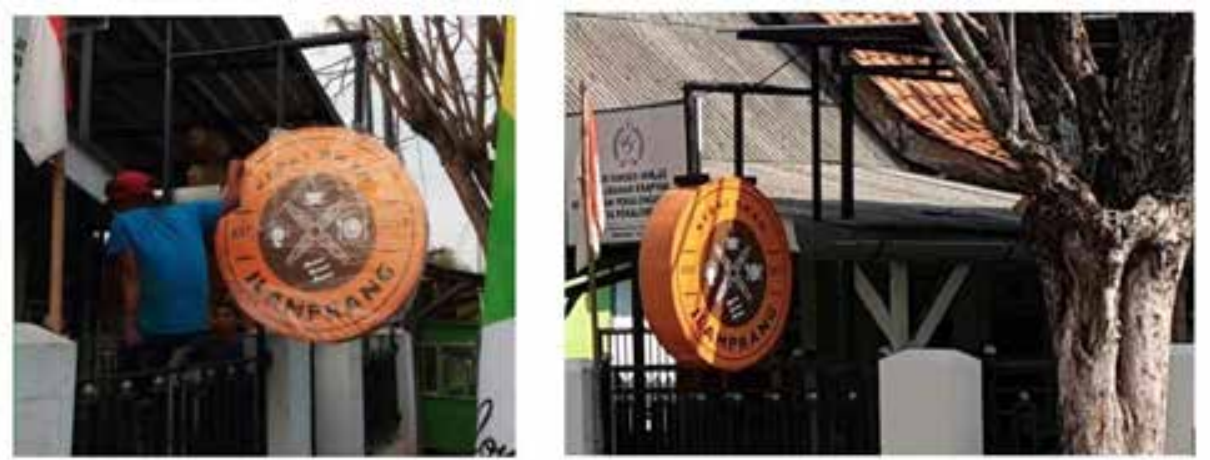

Figure 5. Instalation of Signage Kedai Omah Jlamprang (source: Author, 2019)

The orange color can help increase oxygen supply to the brain, producing a refreshing effect and stimulating mental activity. The orange color makes people feel comfortable. And like the color orange, orange is associated with healthy food and can stimulate appetite (wongcoco.com, 2018). In addition to using orange which is very good psychologically for culinary, orange is a contrasting color so that it becomes the focus of interest. Referring to the journal Laura Christina Luzar, color has several functions, among others, the function of identity, people know according to the color, such as uniforms, flags, company logos, and others. Similarly, the color is used on the identity of this Kedai Omah Jlamprang. (Luzar: 2011). 

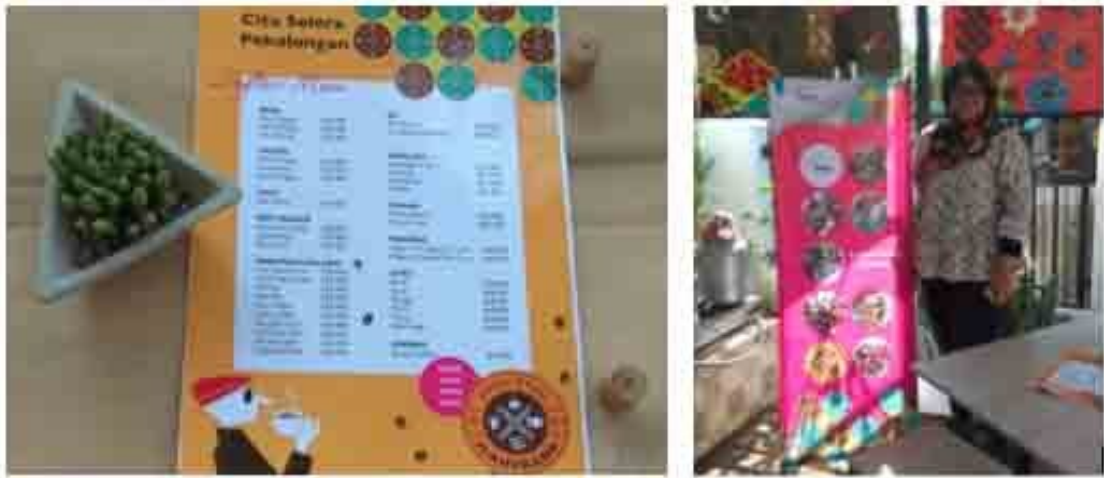

Figure 6. Marketing tools Kedai Omah Jlamprang

(source : Author, 2019)

In addition to preparing for branding materials workshop that consist of identity branding to the application of design in media marketing tools, the visual communication design team with the CDA team and Youth Organization also prepared visual items that support the opening ceremony of Kedai Omah Jlamprang which was inaugurated by the Rector of Binus University and the Vice Major of Pekalongan on August 12, 2019.
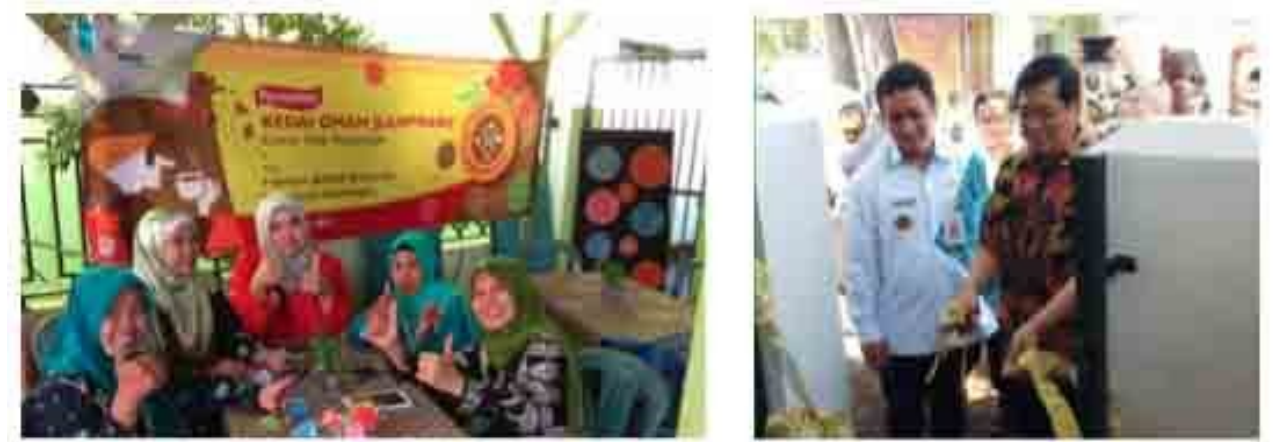

Figure 6. Inauguration of Kedai Omah Jlamprang by Rector of Binus (source: Author, 2019)

\section{CONCLUSION}

Community empowerment in Krapyak area in general has achieved its objectives well. It must always be understood that doing business with SMEs has a long set of processes. Success will only be obtained by involving all elements of empowerment from the community, the Pekalongan city government and Binus University on an ongoing and coordinated basis.

Branding program is different from marketing activities, where marketing activities will attract consumers to try and eventually will be connected through transaction after transaction. But branding activities will ensure that the relationships between managers, stake holders, the public and consumers are strongly influenced by positive activities that reflect the character of Kedai Omah Jlamprang. Branding activities must always be maintained, so that it becomes an ongoing agenda, so that at some point Kedai Omah Jlamprang will grow into a great brand that is scalable and suistanable for the welfare of the Krapyak community in particular.

\section{REFERENCES}

Ernani Hadiyati, (2011), Kreativitas dan Inovasi Berpengaruh Terhadap Kewirausahaan Usaha Kecil, Jurnal Manajemen Dan Kewirausahaan, vol.13, no. 1, maret 2011: 8-16

Monica, Luzar (2011), Efek Warna dalam Dunia Desain dan Periklanan, Jakarta: HUMANIORA Vol.2 No.2 Oktober 2011: 1084-1096

Munawar Noor, (2018), Pemberdayaan Masyarakat, Jurnal Ilmiah CIVIS, Volume I, No 2, Juli 2011 
Mustangin, (2017), Pemberdayaan Masyarakat Berbasis Potensi Lokal Melalui Program Desa Wisata di Desa Bumiaji, Bandung: Departemen of Sociology, Faculty of Social and Political Science, Universitas Padjadjaran

Pujangga, R. F. (2014, December 10). UNESCO Akui Kota Pekalongan sebagai Kota Kreatif Dunia . (T. Jateng, Producer) Retrieved August 5, 2019, from Tribun Jateng.com: https://jateng.tribunnews.com/2014/12/10/unesco-akui-kota-pekalongan-sebagai-kota-kreatifdunia

Oscario, Angela. (2013). Pentingnya Peran Logo dalam Membangun Brand. Jurnal Humaniora, Vol.4 No.1, 191-202, Jakarta: Binus University

Udin, Noor (2011), Langkah Penyadaran Brand Usaha Kecil dan Menengah. Jurnal Humaniora, Vol 2 No.1, Jakarta: Binus University.

Yuswohadi, Dyah Hasto Palupi, Teguh S. Pambudi (2013), Beat the Giant, Jakarta: Gramedia Pustaka Utama.

www.kompasiana.com/trimanah/kabupaten-pekalongan-permata-yang-perlu-diasah

wongcoco.com/detail/329/5-warna-yang-bisa-meningkatkan-nafsu-makan 